\title{
THE CHANGING SECONDARY CURRICULUM IN ENGLAND
}

\author{
Barnaby Lenon*
}

There have been attempts to persuade us that it is more important to learn 'twentyfirst century skills' rather than more conventional knowledge grouped by traditional school subjects. This is nonsense.

In recent years we have seen the growing popularity of science and a decline in modern languages, design technology, music, drama and English (the latter at A Level). The reasons for this are complex.

Too much of the debate about education is about structures: are Academies a good thing or not? What about grammar schools? Are the accountability measures fair? What about the Ofsted inspection regime? These are the things which preoccupy government ministers and the media.

Less is said about the actual content of lessons - what is taught and what we want inside the brains of 11-year-olds, 14-year-olds, 16-year-olds and 18-year-olds.

But I am interested in what pupils actually know. I am interested in the fact that so many of my A Level students had never heard of Martin Luther, that my religious studies GCSE pupils did not seem to know what was meant by the crucifixion - what it was, what its significance was to Christians - despite the fact that the crucifixion lay at the centre of most Europeans' lives before 1945.

In some respects, children in this country know less than they used to, and that is not an accident - it is the result of decisions taken by people who should know better.

What are schools for? They are there to help students make a living after they have left. But they also teach pupils those things which make life worth living, like literature, art, music, drama and sport. These subjects will not often lead to a job, but they are just as important as those subjects that do.

Most sensible people think it's a good idea to teach subjects, because that's the way mankind has classified knowledge and has done so for a reason. Most teachers have taken a degree in a specific subject. It is just a pity that teacher training in England has given so little emphasis to subject knowledge; if you compare teacher training with the training of doctors or lawyers you can immediately see the contrast. With doctors and lawyers there is a huge emphasis on subject knowledge. It could be like that for teachers too.

\footnotetext{
* Professor Barnaby Lenon MA, CBE.
} 
If you believe in subjects then that leaves two further questions:

1. You can't teach all subjects, so which are you going to leave out? For children up to the age of 16 in England the government has defined a high proportion of subjects which should be taught. There is some choice available, but it is limited.

Beyond 16 there is plenty of subject choice within A Levels, the International Baccalaureate and vocational qualifications like level 3 BTECs (agriculture, health and social care, business, construction, engineering and many others). This diversity of choice post-16 helps motivate students.

2. How much time are you going to spend on each subject? English, maths and the sciences are core subjects and require much of the time available. The danger with having too many other subjects is that you spend little time on each. Schools who try to satisfy 11-to-14-year-olds by teaching a long list like French, Spanish, history, geography, RE, art, music, dance, drama, PE, design technology and computing for just one hour or less a week each may not be doing anyone a favour. It is hard to have a sense of momentum on fewer than two periods a week on two different days.

Some successful secondary schools devote much more time than usual to maths and English. They rightly regard these as fundamental academic subjects which have to be mastered before most (not all) other subjects can be handled properly. The reward for their approach is that all their pupils are pretty good at maths and English by the age of 14. The price they pay for spending so much time on maths and English is that some other subjects cannot be taught until Key Stage 4.

In 2013 Cristina Iannelli ${ }^{1}$ at Edinburgh University published research which showed that the subjects a child studied at school had a significant effect on their chances of doing well in life. Taking a cohort of people born in one week in 1958, she found that the subjects they studied mattered more than going to a private school or grammar school. People who studied languages, English, maths and science, regardless of school type, were more likely to enter professional and managerial occupations. So subject choice matters.

\section{TWENTY-FIRST CENTURY SKILLS}

Benjamin Bloom, who died in 1999, was an American educational psychologist who made contributions to the classification of educational objectives. In 1956,

\footnotetext{
1 Iannelli, C. (2014) 'Widening access to higher education: social inequalities in school subject choices matter', British Journal of Sociology of Education.
} 
Bloom edited the first volume of Taxonomy of Educational Objectives: The Classification of Educational Goals, ${ }^{2}$ which outlined a classification of learning objectives that has come to be known as Bloom's taxonomy:

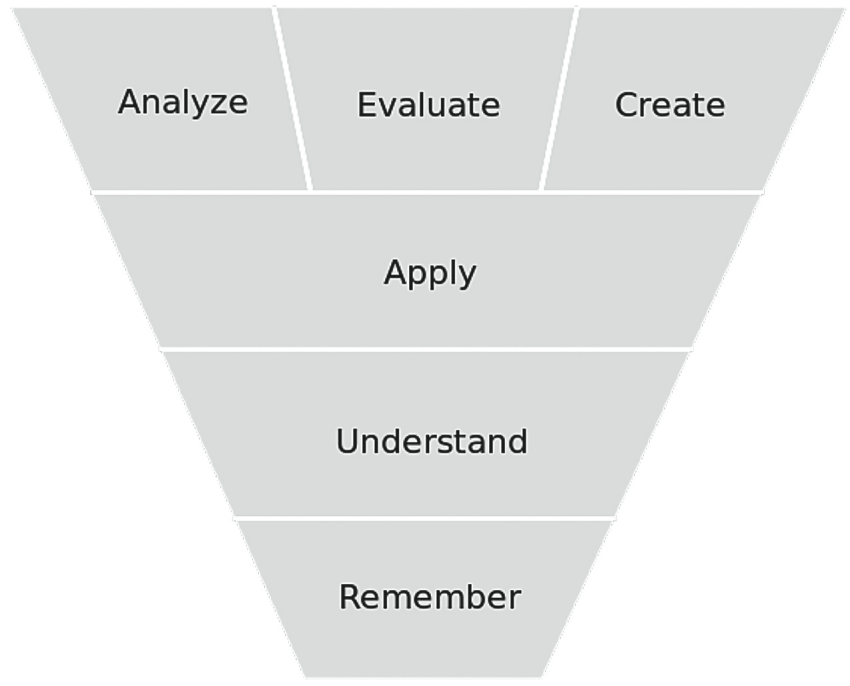

Bloom's taxonomy suggests that remembering something is a low-order skill, while analysing, creating and evaluating are higher-order skills. This in turn suggests that skills are somehow separate from knowledge, and that knowledge is less worthy or important. It encouraged people to think you could skip the lowerlevel bit and jump up to the high-order parts, that what we want is not facts but pupils who are able to reason, be creative and imaginative, to learn collaboratively. This was the basis of the idea that schools should teach skills not knowledge.

In England the National Curriculum was introduced in 1988, and state schools were required by law to teach it. There was, over time, a gradual reduction in subject content and its replacement by skills and experiences. For example, the 2007 Key Stage 3 history curriculum prescribed less knowledge than a list of skills:

\section{Pupils should be able to:}

A. Identify and investigate, individually and as part of a team, specific historical questions or issues, making and testing hypotheses.

\footnotetext{
${ }^{2}$ Bloom, B. (1956) Taxonomy of educational objectives: the classification of educational goals, McKay.
} 


\title{
THE CHANGING SECONDARY CURRICULUM IN ENGLAND
}

B. Reflect critically on historical questions or issues.

C. Identify, select and use a range of historical sources, including textual, visual and oral sources, artefacts and the historic environment.

D. Evaluate the sources in order to reach reasoned conclusions.

The Royal Society of Arts developed a new secondary curriculum for the twenty-first century called Opening Minds ${ }^{3}$, which concluded that there were five essential skills which should be the basis of the school curriculum:

\author{
Citizenship \\ Learning \\ Managing information \\ Relating to people \\ Managing situations
}

These competences are broad areas of capability, developed in classrooms through a mixture of instruction and practical experience: children plan their work, organise their own time and explore their own ways of learning.

Subject boundaries are less defined than in traditional curriculum teaching, with schools often integrating the teaching of several subjects together into modules or topics, where competences can be developed through the exploration of common themes. (RSA website)

In 2018 the CBI called on schools in England to prioritise teaching thought, ${ }^{4}$ questioning, creativity and teamwork. In schools which have adopted this approach the focus of the curriculum is projects, not subjects. Take the UCL Academy in Camden. In 2013 I went to visit this hugely expensive new school, run by one of the UK's top universities. The online prospectus stated:

The first year in the Academy is a year in which students adapt to the unique learning environment which the Academy offers, and prepare themselves to take on the responsibilities for developing their own programme of study in the years ahead. Students develop a wide variety of skills essential for effective learning.

Students study the International Middle Years Curriculum at the Academy as a model of learning which encourages cross-curricular learning through

\footnotetext{
${ }^{3}$ Royal Society of Arts, 2000, Opening Minds, RSA

${ }^{4}$ CBI (2018) Educating for the modern world - CBI/Pearson education and skills annual report.
} 
Big Ideas, an international focus and bookended by Entry and Exit Points, where Big Ideas and concepts are introduced and reviewed.

The school had its first Ofsted in 2014 and was graded Requires Improvement.

I taught an A Level called Critical Thinking. I did it because I thought that critical thinking sounded like a good skill that all educated people ought to have. But I soon realised that this subject was in fact completely bogus. There were a set of rules which one learnt and then applied to the information provided in the exam questions. But these were not rules that could be generally applied outside this specific exam.

What this told me was that it was very hard to teach thinking skills outside the context of a subject. If we teach pupils to think critically about, for example, the causes of the Second World War, this does not mean they can think critically about climate change or alternative energy options. Critical thinking processes are tied to background knowledge. Martin Robinson makes this point:

In order to be critical and creative kids need to know stuff, to have a good grasp of the basics ... only then can they become creative, critical citizens ... (Robinson, 2013) ${ }^{5}$

Or Dan Willingham (2007): ${ }^{6}$

Critical thinking (as well as scientific thinking and other domain-based thinking) is not a skill. There is not a set of critical thinking skills that can be acquired and deployed regardless of context.

Thus, if you remind a student to 'look at an issue from multiple perspectives' often enough, he will learn that he ought to do so, but if he doesn't know much about an issue, he can't think about it from multiple perspectives.

Adults with good thinking skills have developed them by knowing a lot ... not by learning thinking skills. The most reliable basis for twenty-first century skills is possession of wide-ranging knowledge across many subjects. Artificial intelligence and Wikipedia are no substitute for humans knowing things.

\footnotetext{
${ }^{5}$ Robinson, M. (2013) Trivium 21c: preparing young people for the future with lessons from the past, Independent Thinking Press.

${ }^{6}$ Willingham, D. (2007) 'Critical thinking: why is it so hard to teach?' American Educator.
} 
What is more, time spent on teaching thinking skills or competencies rather than subjects carries a high opportunity cost - the pupils are not doing something completely useless, but nor are they using the time as well as they could. Time spent on activities supposed to promote 'transferrable skills' is time not spent learning knowledge that would really build transferrable skills.

\section{THE ALTERNATIVE APPROACH - TEACHING KNOWLEDGE}

E. D. Hirsch was born $1928^{7}$ and is now retired; he was previously the Professor of Education and Humanities at the University of Virginia. During the late 1970s, while giving tests to measure how quickly students grasped ideas from written texts, he discovered that speed of comprehension was determined by the reader's possession - or lack - of relevant background knowledge.

He found that students at the University of Virginia were able to understand a passage about Ulysses S. Grant and Robert E. Lee, while students at a Richmond community college struggled with the same passage, because they lacked a basic understanding of the American Civil War. This led Hirsch to formulate the concept of cultural literacy - the idea that reading comprehension requires not just the skill of decoding letters and words, but also wide-ranging cultural background knowledge. He concluded that schools should not be neutral about what is taught, but should teach a highly specific curriculum that would allow children to know things that writers tend to take for granted.

His book on the subject, Cultural Literacy: What Every American Needs to Know, was published in $1987 .{ }^{8}$ Beginning in the 1990s, Hirsch began publishing the Core Knowledge Series, where each book focuses on the precise knowledge that should be taught to children at each age.

E. D. Hirsch has been an important influence on Nick Gibb MP, the schools' minister in England for much of the period 2010-2020. I happened to be a vicepresident of the Royal Geographical Society in 2011 when I was asked to help write the Geography National Curriculum for children aged 5-16, including a revised GCSE syllabus.

It was striking that when I was called in to see Minister Gibb with my proposals he had a copy of Hirsch's Core Knowledge open on the desk in front of him. After a bit of banter he approved our plan but then asked, 'And who will write the

\footnotetext{
${ }^{7}$ Hirsch, E. D. (1987) Cultural literacy: what every American needs to know, Houghton Mifflin

${ }^{8}$ Hirsch, E. D. (2016) Why knowledge matters: rescuing our children from failed educational theories, Harvard Education Press.
} 
textbook?' This is an important question because he understood that, while a new syllabus is a good start if you are reforming a subject, the level of detailed knowledge would be determined by the textbook writers.

It was Michael Gove's main achievement as Secretary of State for Education (2010-14) that he set in motion the reform of the syllabus content for the National Curriculum (what children aged 5-14 study) of GCSEs and of A Levels. The knowledge content of National Curriculum and GCSE subjects was greatly increased, especially in mathematics. At the same time, incidentally, the number of examinations sat was greatly reduced.

The ideas of E. D. Hirsch have been promulgated in England by a group called Parents and Teachers for Excellence. They claim that the best schools in the country - in the state and private sector - tend to have a number of key characteristics in common:

- The highest standards of behaviour are expected in the classroom and around the school.

- They teach a challenging curriculum that stresses the importance of knowledge.

- Children are tested regularly so their progress can be measured and teaching amended accordingly.

- Interesting, stretching and culturally enriching extra-curricular activities are standard.

Much evidence suggests that they are right.

\section{EBACCHANALIA}

Before 2019 the Russell Group of 24 leading universities produced a guide for schools in which they stated that some A Level subjects are more useful than others if you want to keep your options open in terms of admission to Russell Group universities. These so-called facilitating subjects were maths, further maths, physics, chemistry, biology, modern and ancient languages, English literature, geography, history, philosophy and ethics.

The Government was concerned that increasing numbers of pupils were studying non-facilitating subjects, and this was especially true of pupils from disadvantaged backgrounds. In order to influence this, they created a new performance table measure called the English Baccalaureate (EBacc) which gives the proportion of a school's students passing GCSEs in English, maths, sciences, history or geography and a language. 
Just 22 per cent of state school pupils were entered for the EBacc in 2010, the year it was introduced. GCSE results in 2019 showed that the proportion entering the EBacc had risen to 40 per cent. So this was a remarkable example of a performance table tweak having a huge effect on what was being taught in English schools.

A further measure called Progress 8 was introduced for schools in 2016 based on students' progress in eight subjects: English; mathematics; three other EBacc subjects (chosen from sciences, computer science, geography, history and languages); and three further subjects.

The EBacc was given extra punch in 2016 when the floor standard (the standard a school had to reach if it was to avoid intervention by the Department of Education) was based on schools' results on the Progress 8 measure. The EBacc performance measure was a nudge. The EBacc element of Progress 8 is really compulsion.

\section{THE NATIONAL CURRICULUM IN ENGLAND}

For maintained schools the post-2014 National Curriculum subject requirements were set as follows:

\section{Key Stage, 1 age 5-7}

English, maths, sciences, history, geography, religious studies, art, music, computing, design and technology, physical education

Key Stage 2, age 7-11

The same but add foreign language (ancient or modern)

Key Stage 3, age 11-14

Add citizenship, sex education. Languages must now be modern.

Key Stage 4, age 14-16

English, maths, sciences, computing, citizenship, religious studies, sex and relationships, physical education

This implied there was a hierarchy of subjects up to the age of 16 :

Vital: English and maths - double weighting in Progress 8

Other EBacc subjects: Physics, chemistry, biology, computer science, history, geography, languages ancient or modern

Others: art, music, design technology, PE, RE, dance, media, sociology, business, etc. 
This is not a bad recipe for those pupils who wish to maximise their university prospects. But while some of the advanced maths of the reformed GCSE may well be good for the country, it is perhaps less important for many individual children. I am not sure that rudimentary foreign language acquisition is at all essential for most. What is essential is a basic grasp of English and maths for all, followed by exposure to the individual subjects where each child can best show their ability and which have a good chance of generating motivation. Without motivation school can be a bit of a waste of time. I have known many pupils whose school life (and career prospects) was transformed by a non-EBacc subject such as music, drama or sport.

So the Key Stage 3 and 4 school curriculum choices can be influenced by several considerations:

1. the skills you believe the economy of the nation needs in the future.

2. the things you believe that 'all educated people should know', regardless.

3. the curriculum that is most likely to keep career options open longest (you will struggle to be a doctor if you drop chemistry).

4. the need to limit choices because of teacher supply and the financial advantages of keeping the number of options low.

5. a wish to offer subjects which are motivating to many individual young people.

6. a belief that children from disadvantaged homes have been given a raw deal by schools allowing them to take subjects which have very little value in terms of either university entrance or careers - so the state must intervene to stop this.

Since 2010 we have had a relatively stable set of policies being implemented by the Department for Education. The focus has been on traditional school subjects and on raising the level of knowledge. To some extent we have been influenced by the PISA tests, which have shown that other countries, not least in East Asia, are well ahead of England. So pupils in England are now expected to know more than they did.

\section{CREATIVE ARTS SUBJECTS}

The arts world has been very exercised by the EBacc, because arts subjects are optional at GCSE. The pattern of GCSE entries from all schools in the UK in creative subjects is shown below. In the past ten years here has been a small decline in music and drama, no real decline in art relative to the overall numbers taking GCSEs, a big decline in design technology. 


\section{THE CHANGING SECONDARY CURRICULUM IN ENGLAND}
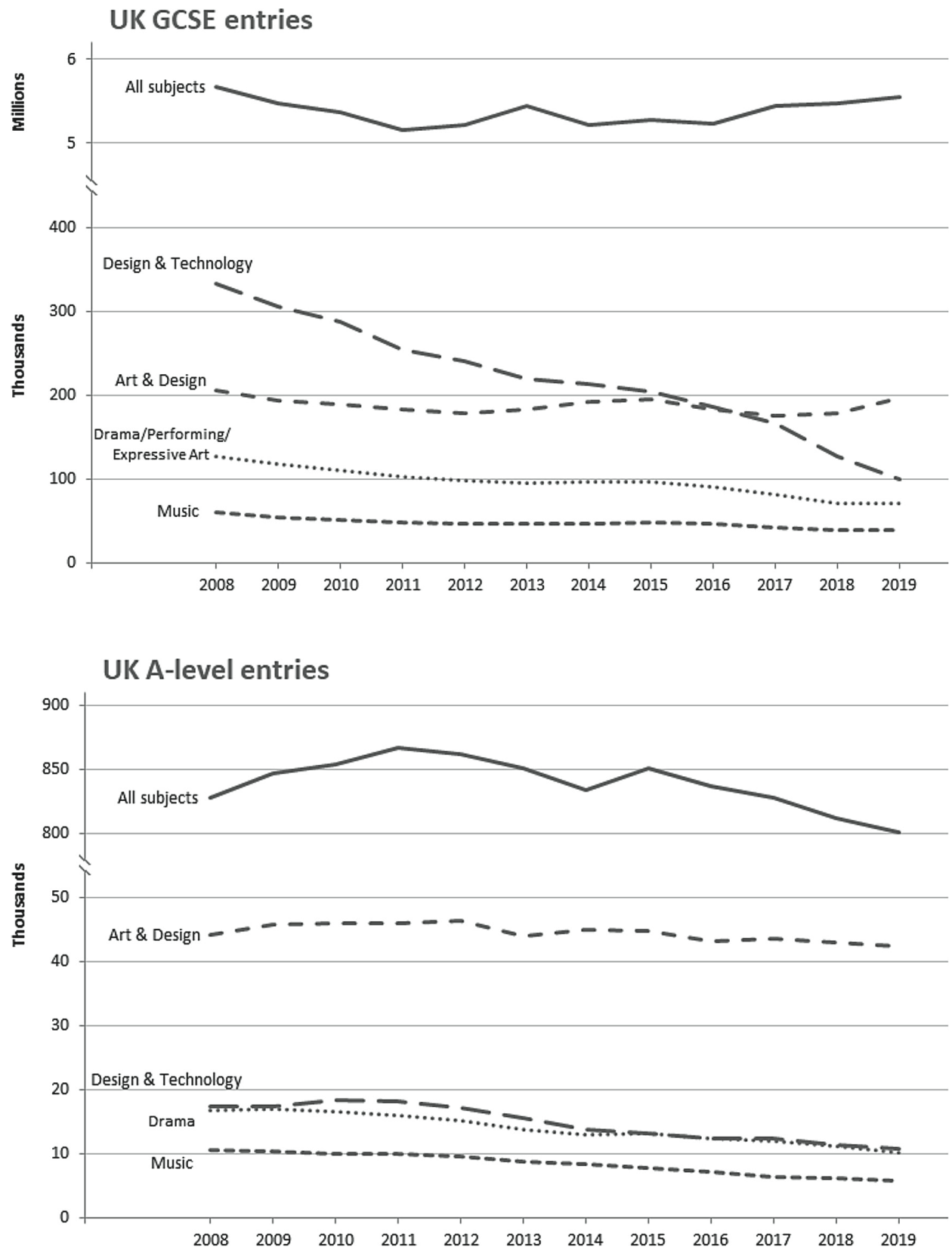

The proportion of pupils taking at least one arts GCSE has in fact not changed much over the past decade: $47 \%$ in 2010, $44 \%$ in 2018. 
But music, for example, has suffered some decline. The average A Level music class now has just three students. According to the research commissioned by the Royal Academy of Music and the Royal College of Music, a fifth of entries for the subject are from fewer than 50 schools. Numbers taking music A Level in England fell from 8,790 in 2010 to 5,124 in 2019. Independent schools account for a disproportionately high number of A Level music entries, and the subject is disappearing altogether from some schools in deprived areas.

Apart from the EBacc and the Russell Group list of facilitating subjects, both of which may have given the impression that arts subjects were of lower value, what else could account for the small relative decline in creative subjects? There has been greater emphasis on the vocational value of school subjects, and sciences have been, rightly or wrongly, seen as more valuable. There has been pressure on teaching time and budgets. 'Core' subjects are timetabled first and often given more curriculum time. Option blocks are changed to reflect the curriculum hierarchy and students' choices are limited. Extra-curricular time gives way to 'interventions' (extra tuition) in core subjects. Budget pressures mean that money is less available for visits to galleries, theatres, museums or for bringing in arts specialists into the school. Arts subjects are often expensive and budgets have been tight.

\section{DESIGN AND TECHNOLOGY}

In terms of status, design and technology has come and gone over the past 30 years. The number taking DT GCSE in the UK in 2003 was 440,000; by 2019 the figure was 99,700. In July 2016, 87 MPs wrote a letter to the Prime Minister:

The UK faces a number of challenges:

An annual shortage of 69,000 trained engineers

Only 6\% of the UK's engineering workforce is female

As a result of schools being judged on their EBacc results, many of them are pushing their students - particularly 'academic' students - to do as many Ebacc subjects as possible; more than the minimum five. The result is that $D \& T$ is being squeezed into a single or double option box, to compete with subjects like Photography and Dance for a single place among student options. This is a problem in any case, but would be tragic for the new D\&T GCSE - which is academically rigorous and sits comfortably alongside the EBacc subjects.

They were quite right to mention photography and dance, because in the end it is all about space in the timetable. D\&T is a great subject, but it is being crowded out. 


\section{ENGLISH A LEVELS}

English has long been a staple A Level subject, but there has been a $31 \%$ decline across all three English A Level subject specialisms between 2012 and 2019, with a 13.5\% decline between 2018 and 2019. The decline in A Level English language and literature is most alarming, with a 56\% reduction since 2011. The picture is almost as bad for A Level English language, where the figure is $42 \%$. For A Level English literature the number is $25 \%$.

In October 2019 the English and Media Centre carried out a survey and concluded that the decline had two causes: the tough and slightly dull nature of the reformed GCSEs in English language and literature, and the greater vocational value attached to STEM subjects.

\section{MODERN FOREIGN LANGUAGES (MFL)}

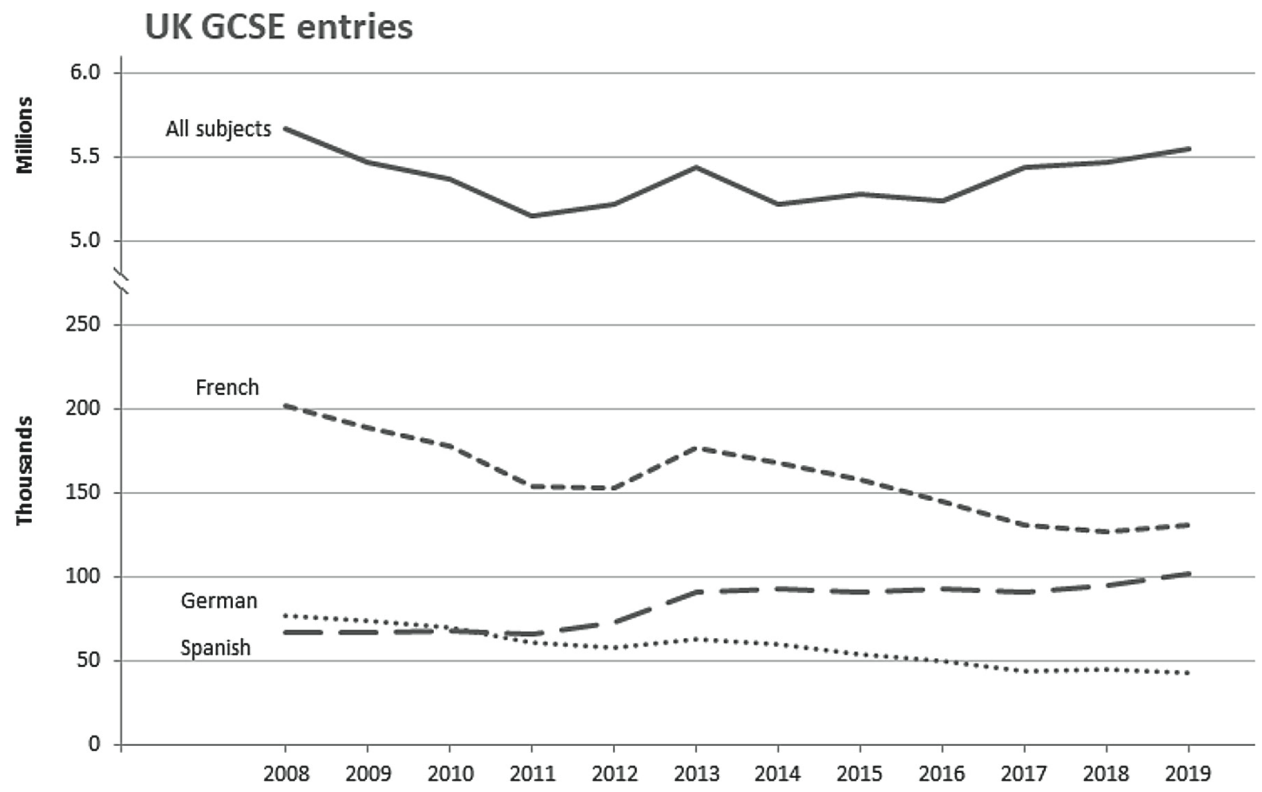

Overall numbers taking modern languages have been falling for some years. Spanish numbers have grown, but not as much as French and German declined. 31,261 in the UK took A Level French in 1992; despite a huge increase in overall numbers of A Levels taken, the figure in 2019 was only 8,355. In Britain, only 34.6 per cent of people aged between 25 and 64 report that they know one or more foreign language, compared with an EU average of 64.8 per cent. 
We know that this was partly the result of the decision taken in 2002 to make MFLs optional at GCSE. It is partly because MFLs are harder subjects than some of their competitors (even though standards have fallen further in MFLs than in other subjects since the 1980s. A Level French is about the same standard as the O Level was then). In 2019 Ofqual decided to lower grade standards in GCSE French and German after finding they are more harshly graded than other subjects.

The arrival of more and more native speakers in the UK has also put pressure on the system. They take A Levels in their home language and, because top grades are rationed, this makes it harder for non-native speakers to gain the higher grades. This is especially true of Mandarin.

After 2010 the government made modern languages an EBacc subject and numbers rose. However, from 2016 modern languages were an optional part of the Progress 8 GCSE measure and progress has stalled.

There have been problems with the language teaching methods used in schools. Teachers adopted methods used by those teaching English as a foreign language, where the focus is on speed of acquisition and spoken language. Teaching in the target language has been a mistake, because it frightens off many pupils and doesn't make use of their knowledge of English. There has been too much focus on 'speaking in a café, too little formal grammar, almost no translation of English to French, and far too much rote learning of phrases which gives a false impression of competence.

A Level syllabuses have been boring, with little or no study of literature. Much has been intellectually poor and dull. The ALCAB (A-level Content Advisory Board) report in $2014^{9}$ spells it out:

The panel identified weaknesses in the current AS and A level:

(a) The regulatory requirements are of such a general nature that they do not require awarding organisations to prescribe topics which require students' direct engagement with material relating to the society of the countries where the language of study is spoken.

(b) The study of cultural topics is only an A2 option and general topics predominate, some of which are studied and restudied at GCSE, AS and A level. Despite examples of good practice by awarding organisations and inspiring teaching, this can make the current syllabus rather dull and uninspiring.

9 ALCAB (2014) The A-level Content Advisory Board Reports, ALCAB. 


\section{THE CHANGING SECONDARY CURRICULUM IN ENGLAND}

Notwithstanding examples of good practice by awarding organisations in this area and of inspired and inspiring teaching, such arrangements have contributed for some students to a repetitive and hence rather dull and uninspiring learning experience, less stimulating than is provided by other related subjects at GCE, such as English, history and classics.

The result of this diminution of content has been an impoverishment of students' curiosity-driven learning. Cognitive stimulus is largely restricted to practical language learning, together with what teachers may bring to the subject over and above the requirements of the qualification. Hence, the cognitive challenge at GCE in modern languages is met only inconsistently. That challenge is to communicate increasingly complex messages, necessitating the use of more complex structures to connect ideas about increasingly complex material. The panel believes that this weakness makes the qualification less rewarding and less engaging for high-achieving students. That, together with perceptions of severe grading, can discourage students from selecting a modern language A Level.

(c) The language of study tends to be conceived principally in terms of its immediate practical use and in isolation from the student's competence in other languages. There is therefore no encouragement to develop a more searching understanding of linguistic systems.

Dull, dull, dull. The revised GCSE and A Level syllabuses aim to turn this round, but it may be too late. The decoupling of the AS from the A Level hits MFL more than other subjects because the gap between GCSE and A Level is greater: the AS was a useful stepping stone. Furthermore, the decoupling has encouraged schools to offer just three A Levels in year 12 rather than four AS Levels. An MLF was often the fourth choice for pupils, so this change must result in further decline.

University language departments are closing fast. There are now fewer MFL graduates each year than there are MFL teacher training places.

\section{GENDER AND SUBJECT CHOICE}

It is remarkable, given that almost all children are taught in mixed-sex schools, that gender stereotypes still influence subject choice in the way they do. 
For example, look at some UK A Level entries in 2019:

\begin{tabular}{|l|l|l|}
\hline & Male & Female \\
\hline Physics & 30,159 & 8799 \\
\hline Computing & 9649 & 1475 \\
\hline Economics & 21,557 & 9284 \\
\hline French & 2515 & 5840 \\
\hline English Lit & 9153 & 31,671 \\
\hline Psychology & 16,500 & 48,098 \\
\hline Sociology & 8659 & 29,356 \\
\hline
\end{tabular}

Source: Joint Council for Qualifications website

Only Geography and Chemistry seem to avoid the gender bias.

For a range of subjects there is a very clear sense that they are 'female' or 'male'. Schools need specific policies to overcome the negative effects of gender bias on subject choice.

\section{CHARACTER EDUCATION}

In 2019 the Secretary of State for Education set out 'Five Foundations' for character education: Sport; Creativity; Performing; Volunteering \& Membership and the World of Work.

Soft skills like good manners, how to speak well, determination, initiative, leadership, teamwork, kindness, optimism and self-motivation are all crucially important to a person's prospects in work. But, on the whole, these can be taught through normal lessons and the co-curricular programme. There is no need to have a separate curriculum just for them.

The University of Birmingham School promotes itself specifically on the basis of character development. Their website states:

Character Education is about acquiring and strengthening virtues - traits that sustain a well-rounded life and a thriving society; values such as compassion, humility, sensitivity, creativity, curiosity, determination and resilience.

They aim to achieve this through enrichment activities such as sport and by encouraging teachers to refer to the values and virtues whenever possible through the academic curriculum. 
There is some evidence for the value of character education. Durlak et al. conducted a meta-analysis of 213 school-based social and emotional learning programmes involving 270,034 kindergarten to secondary school students. Compared to controls, the programme participants demonstrated significantly improved social and emotional skills, attitudes, behaviour and academic performance (Durlak, 2011). ${ }^{10}$

But there is little other evidence that specifically teaching 'character' works. One reason is that a proportion of a person's character is determined by their genes, including things like grit and resilience. The King's College London Twins Early Development study suggests that genes determine between a third and a half of any given characteristic in the population (Plomin, 2018). ${ }^{11}$

Paul Tough's analysis of the research (Tough, 2013, $\left.{ }^{12} 2016\right)^{13}$ leads him to believe that character is best developed not by having character lessons in school but by parents and teachers modelling the sort of behaviour they identify as important. It is the day-to-day living environment that matters. My generation had endless lectures at school about the damage to our lungs caused by smoking but none of it worked. Teenagers don't respond to theory. What they do respond to is encouragement and compulsion, especially teenage boys. The most effective measure to cut smoking has been to make it illegal to smoke in public places. Similarly, the most effective way to make boys work hard is to force them to work hard - by threatening them, if necessary, with punishments which outweigh the pain of hard work. But once they have learnt that hard work pays off (which they do), then the penny drops.

\section{THE VOCATIONAL CURRICULUM}

In 2010 there was concern that schools and colleges were encouraging pupils to take subjects which were of little value to universities or employees. The 2011 Wolf Report, written by Professor Alison Wolf from King's College London, ${ }^{14}$

${ }^{10}$ Durlak, J. Weissberg, R. Dymnicki, A. Taylor, R. \& Schellinger, K. (2011) 'The impact of enhancing students' social and emotional learning: a meta-analysis of school-based interventions', Child Dev 82.

${ }^{11}$ Plomin, R. (2018) Blueprint: how DNA makes us who we are, MIT Press and Allen Lane.

12 Tough, P. (2013) How children succeed: grit, curiosity and the hidden power of character, Ransom House.

13 Tough, P. (2016) Helping children succeed: what works and why, Random House.

${ }^{14}$ Wolf, A. (2011) Review of vocational education: the Wolf Report, Gov.uk. 
found that thousands of vocational qualifications taken by young people were a 'negative qualification' - in other words they actually harmed a pupil's prospects of going to university or gaining a job.

In response to her findings, the government removed funding from these courses and reduced the incentives which had encouraged schools to offer vocational alternatives to GCSEs: in government league tables there had been a raft of generous 'equivalences' where, for example, a vocational ICT course was worth the equivalent of four GCSEs. These equivalences were often far easier than the GCSEs they were supposed to be the equivalent of. They were reined back after the Wolf Report.

The result of this is that vocational courses are not available to students until after they have taken their GCSEs. They are an alternative to A Levels:

1. Applied General qualifications are vocational courses that can be a route to higher education as well as a path to a job or apprenticeship. They include BTECs, Cambridge Technicals, Diplomas and level 3 Certificates. Applied General qualifications provide learning in a vocational area, for example applied science, business or sport. About a quarter of students going to university have BTECs.

The term 'applied general' is a dreadful one that should be dropped as soon as possible. It means nothing to most people.

2. Functional skills are entry level, level 1 and 2 courses in English, maths and ICT for students who only got a poor grade in the GCSE.

3. Technical and vocational education often comprises one- or two-year college courses. Some equip students with the specialist knowledge they need for a specific occupation, such as engineering, computing or hospitality. Others are more general - they provide wider employability skills.

From 2020 these existing courses will be joined by T Levels, in an attempt to create vocational courses which have parity of esteem with A-levels. They will be 80 per cent classroom-taught, 20 per cent practical experience with a minimum of 45 days' employer placement, and will include English, maths and digital skills. One T Level will be the equivalent of three A Levels.

4. Employment-based apprenticeships (a mixture of paid work and training).

A main function of GCSEs and A-levels is to put students in rank order for the purposes of university or college entry and to enable employers to select on the basis of academic competence should they wish to.

But the main function of vocational qualifications is not to put students in rank order. Their aim is to create employability and to confirm whether students can, or cannot, perform a series of defined technical tasks - yes or no. 
Vocational education in England is still quite weak despite it being a concern since as early as 1867 ! T Levels are a step forward, but there is a long way to go.

The school curriculum has been comprehensively shaken up since 2010. Now would be a good time to leave things alone so that teachers become better and better at teaching these new courses. Reform of vocational education has hardly started however; this is the great challenge for the next decade. 